\title{
Typology of hydrological structures modelled and observed over the Bay of Biscay shelf
}

\author{
BENJAMIN PLANQUE $^{1}$, PASCAL LAZURE ${ }^{2}$ and ANNE-MARIE JEGOU ${ }^{2}$ \\ ${ }^{1}$ IFREMER, Département Ecologie et Modèles pour l'Halieutique, Rue de l'Ile d'Yeu, B.P. 21105, 44311 Nantes \\ Cedex 3, France. E-mail: benjamin.planque@ifremer.fr \\ ${ }_{2}^{2}$ IFREMER, DEL/AO, BP 70, 29280 Plouzané, France.
}

\begin{abstract}
SUMMARY: Collecting hydrological observations over the whole Bay of Biscay continental shelf can require several weeks. As a result, the observations are not truly synoptic and the interpretation of hydrological structures is corrupted by the time-lags between observations at distinct locations. We evaluated the effects of non-synoptic sampling during a spring cruise (17 April to 13 May 2000), using outputs from 3D hydrodynamic models as a substitute for true synoptic sampling. We developed a method for clustering hydrological regions based on the vertical structure of the water column and temporal changes in hydrography. In parallel, outputs from the 3D model were compared with field observations. The results show that in spring 2000 the Bay of Biscay continental shelf could be separated into six principal hydrological regions, one of them being characterised by vertical stability and low temporal variability. This region corresponds to an area where pelagic fish spawning activity is known to be persistently low.
\end{abstract}

Keywords: Bay of Biscay, clustering analysis, hydrodynamics, spatial-temporal interactions, typology.

\begin{abstract}
RESUMEN: TIPOLOGía DE LAS ESTRUCTURAS HIDROLÓGICAS MODELADAS Y OBSERVADAS EN EL GOLFO DE ViZCAYA. - La recogida de datos hidrológicos en el conjunto de la plataforma continental del Golfo de Vizcaya puede requerir varias semanas. Como resultado, estas observaciones no son verdaderamente sinópticas y la interpretación de las estructuras hidrológicas está perturbada por los desfases temporales entre observaciones de distintas localidades. En este estudio, se evalúan los efectos del muestreo no sinóptico durante una campaña de primavera (17 de abril al 13 de mayo de 2000), usando los resultados de modelos hidrodinámicos tridimensionales como sustituto de un muestreo verdaderamente sinóptico. A través del método cluster se realizó una agrupación de las regiones hidrológicas, sobre la base de la estructura vertical de la columna de agua y los cambios temporales en la hidrografía. En paralelo, las simulaciones del modelo tridimensional son comparadas con las observaciones in situ. Los resultados muestran que en la primavera de 2000 la plataforma continental del Golfo de Vizcaya puede separarse en 6 regiones hidrológicas principales, una de las cuales se caracteriza por una estabilidad vertical y una baja variabilidad temporal. Esta región corresponde a un área donde se conoce que de manera persistente la freza de peces pelágicos es limitada.
\end{abstract}

Palabras clave: Golfo de Vizcaya, cluster, modelización hidrodinámica, interacciones espacio-temporales, tipología.

\section{INTRODUCTION}

The Bay of Biscay continental shelf extends from approximately $43^{\circ} 30^{\prime} \mathrm{N}$ to $48^{\circ} 30^{\prime} \mathrm{N}$. Along the French coast, it is narrow at its southern bound (a few kilometres) and wide at its northern end (up to $150 \mathrm{~km}$ ). The shelf is characterised by a large number of highly dynamic mesoscale hydrological structures (e.g. fresh water lenses, tidal fronts, coastal currents, mid-shelf 'cold pool' and coastal upwellings) which can be observed in different locations, seasons and years (see e.g. Le Cann, 1982; Koutsikopoulos and Le Cann, 1996; Bardey, et al., 1999). These structures affect biological processes, and are thought to be responsible in particular for interannual variations in fish population 


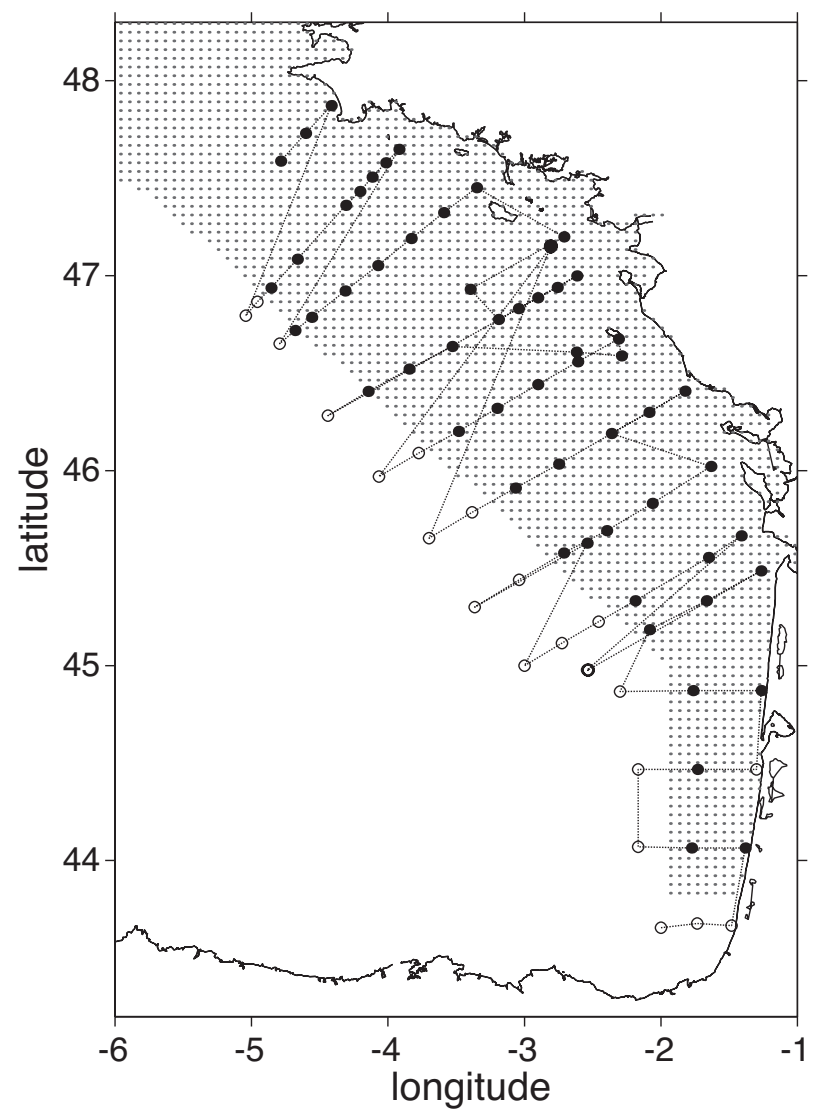

FIG. 1. - The PEL2000 cruise. Circles: location of CTD casts retained (closed circles) and not retained (open circles) in the analysis. Dots: 3D hydrodynamic model grid points. Thin line indicates cruise track, with main direction from south to north.

recruitment (Borja, et al., 1996; Borja, et al., 1998; Allain, et al., 2001) and to modulate the geographical distribution of plankton and fish (Poulet, et al., 1996; Varela, 1996; Labry, et al., 2001). The identification of such structures is therefore of immediate interest for studies concerned with the spatial distribution of fish and plankton in the Bay of Biscay.

In spring 2000, the large-scale survey PEL2000 covering the entire Bay of Biscay French continental shelf was undertaken. During this cruise, vertical hydrological profiles were collected alongside biological sampling activities. The present study set out to define a typology of the hydrological regions over the continental shelf during spring 2000.

The PEL2000 cruise lasted for 26 days (from 17 April to 13 May 2000), with sampling carried out from south to north (Fig. 1). During the time of the cruise, important changes in the hydrology took place. For example, solar heating of surface water resulted in a warmer SST (sea surface temperature) at the end of the cruise (in the north) than at the beginning of the cruise (in the south). The resulting geographical distribution of SST (warmer water in the north than in the south) is contrary to what is normally observed with synoptic sampling (e.g. using satellite infrared imagery). Any geographical typology of hydrological structures, if based solely on information collected during the cruise, is likely to be altered by such temporal effects.

In this article, we describe how we resolved this spatio-temporal interference by using 3D hydrological modelling to mimic synoptic sampling on the Bay of Biscay continental shelf and to correct for the time-lag effect. From the model, we define a typology of hydrological regions during the time of the cruise and compare this typology to what can be observed using the cruise sampling plan. Finally, we compare the model's results to the actual observations and emphasise some of the current strengths and weaknesses of the hydrodynamic model.

\section{DATA AND METHODS}

Hydrological data were collected at 77 stations using a Seabird CTD (Conductivity, Temperature, Depth) probe, from surface to bottom (max sampling depth $200 \mathrm{~m}$ ). Only the 56 hydrological stations for which corresponding hydrological model results were available were retained in this study (Fig. 1). The dates of sampling ranged from 17 April to 13 May 2000.

The 3D hydrodynamic model used covered the continental shelf on a 5 by $5 \mathrm{~km}$ grid, with 10 vertical layers in sigma coordinates (i.e. layer thicknesses are proportional to bottom depth). The model ran with realistic wind and river runoff forcing conditions. The initial conditions were derived from model runs over previous years without correction for possible drift in hydrological parameters. In the simulations for the 15 year period, the model was able to reproduce the main features of seasonal variations of temperature and salinity, and comparisons with survey data (Lazure and Jégou, 1998) confirm the simulated salinity patterns. The only observed drift in the simulated parameters concerns bottom temperature. Free surface open boundary conditions were produced by a larger model extending from Portugal to the North Sea (Lazure and Jégou, 1998). Temperature at the open boundary was interpolated, whereas salinity was relaxed toward 35.6 when currents entered the domain. Therefore, in this first approach, variability in external hydrological condi- 
tions was not taken into account. The model outputs were averaged every 4 tidal cycles (approximately 2 days, a compromise between time resolution and storage capacity). In the comparison of the model's results with the observations, the model was sampled following the PEL2000 sampling plan, i.e. data were extracted from the model grid points closest to actual stations, on the simulation dates nearest to the true sampling dates.

The hydrological typology was constructed in 2 steps. First, a limited number of hydrological parameters were selected and second, a clustering procedure was applied to the modelled data to define the hydrological types.

The selection of hydrological parameters was based on four criteria:

- The parameters had been observed and modelled. This was requested so that the same methodology could be applied to field observations and to model outputs.

- The parameters were relevant for hydrology and biology. This is a more subjective criteria, which was used as a way to include expertise in physical and biological oceanography.

- The parameters were less variable in time than in space. To produce a typology from field observation with minimal time-lag sampling effects, it is necessary to select for the parameters which tend to be well structured in space and display lesser variations in time. This criterion was objectively assessed from the model outputs by measuring the ratio of temporal variance (mean temporal variance at each sampled station for the time of the cruise) over spatial variance (mean variance between all stations at each sampling date of the cruise). The lowest ratio was obtained for bottom salinity $(0.036$, i.e. little variance in time in comparison with geographical variance) and the highest for sea surface temperature $(6.65$, i.e. temporal variance due to warming and thermal stratification far exceeds geographical differences). SST was therefore excluded from the analysis.

- The number of parameters retained should be small.

Four parameters were finally retained: bottom temperature, surface salinity, mixed layer depth and potential energy deficit (see appendix for details on the calculation of the last 2 parameters).

The typology of hydrological regions was done on the basis of these four parameters, using the Kmeans clustering methods. Contrary to agglomera- tive clustering algorithms in which groups are constructed by progressive agglomerations of individual element, $\mathrm{K}$-means is a disjunctive technique in which groups are constructed by breaking the whole data set into predefined numbers of subsets. One advantage of the method is its capacity for handling large data sets such as the one provided by the hydrodynamic model (4081 grid points x 13 dates $\mathrm{x}$ 4 parameters). The technique uses a measure of multiparametric distance between observations. In the present case, the distance between hydrological profiles is the Euclidean distance calculated in a multidimensional space. The position of a profile in each dimension is given by the value of one of the hydrological parameters, after normalisation to zero mean and unit variance (so that each parameter is given the same weight). More details on K-means clustering can be found in Jain and Dubes (1988). Two types of clustering were performed. In the first clustering, termed 'static', each station at each date is described by four parameters (bottom temperature, surface salinity, mixed-layer depth, potential energy deficit). In this approach, each group is constituted by stations (model grid nodes) with similar hydrological parameters but the temporal changes in hydrological parameters are ignored. In the second clustering, termed 'dynamic', each station is described by the value of the same four parameters (bottom temperature, surface salinity, mixed-layer depth, potential energy deficit) on every date during the survey. In this approach, each group is constituted by stations (model grid nodes) with similar hydrological parameters and similar temporal changes. Stations with a salinity of less than 30 were excluded from the analysis. The number of groups to retain in each clustering was determined using an index of clustering efficiency. This index is a measure of the ratio of similarities between objects of the same groups and dissimilarities between objects of different groups (Davies and Bouldin, 1979).

\section{RESULTS}

\section{Static clustering}

The static clustering of modelled hydrology resulted in the construction of 6 groups, each characterised by a mean profile for the four hydrological parameters (Fig. 2). Some groups stood out from the average patterns of hydrology in the Bay of Biscay. 

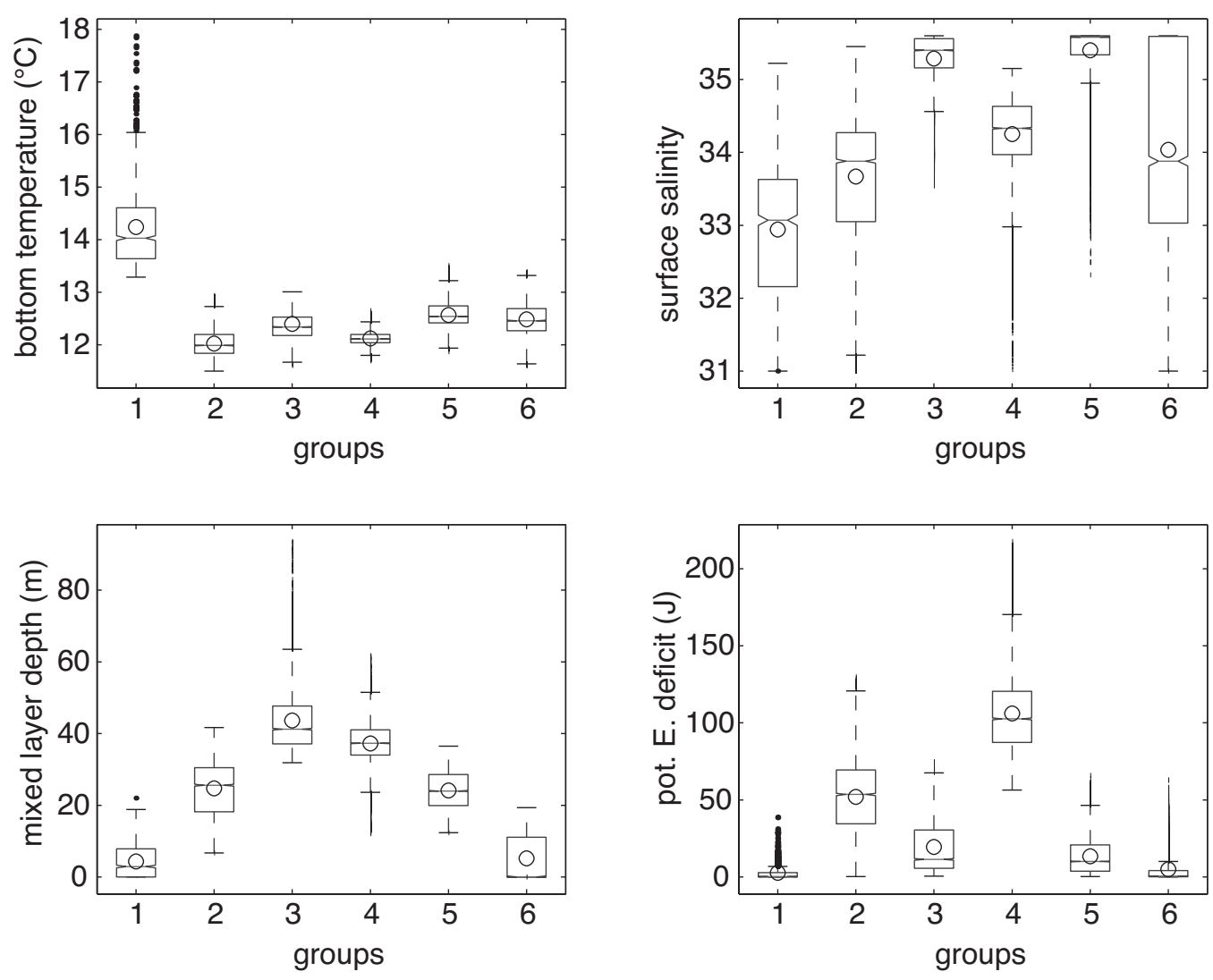

FIG. 2. - Characteristics of the 6 hydrological types revealed by static clustering analysis of the hydrodynamic model (see method section for details). Each group/type is defined by the profile of the four hydrological parameters: bottom temperature, surface salinity, potential energy deficit and mixed layer depth. Open circles display the centroid value of the group for each parameter. The centroid represents the mean position of the group. Box and whiskers plots illustrate the dispersion of parameter values within groups. The box has lines at the lower quartile, median, and upper quartile values. The whiskers are lines extending from each end of the box to show the extent of the rest of the data. Outliers are data with values beyond the ends of the whiskers (whisker length is limited to 1.5 inter-quartile).

For example, group 4 had a high potential energy deficit, a deep mixed layer and a relatively low bottom temperature. Group 1, on the other hand, had a high bottom temperature and a shallow mixed layer. Groups 3-6 are best described by the combinations of the four variables, as shown in Figure 2. The cartography of the spatial distribution of the groups (not shown) reveals important changes in the hydrography of the Bay of Biscay during the time of the cruise. In some areas, the modelled hydrography changed group several times, indicating rapid changes in the vertical hydrological structure. Conversely, the central area of the northern part of the shelf appeared to be stable during the time of the cruise and was represented by hydrological group 4 during the whole cruise duration.

\section{Dynamic clustering}

The dynamic clustering performed on the modelled hydrography allows the regions to be grouped according to their hydrological profile as well as to the changes in hydrology over time. The typology of hydrological regions in spring 2000 is summarised in Figure 3. Group 1 showed a rapid increase in the mixed layer depth at the beginning of the cruise, whereas group 2 displayed the reverse pattern. Group 3 displayed an increase in potential energy deficit, mainly due to a decline in surface salinity. Group 4 was stable over time, and had a high potential energy deficit and a deep mixed layer (this group corresponds to group 4 in the static clustering). The pattern of group 5 was similar to that of group 2 but with a slightly lower bottom temperature and surface salinity. Finally, group 6 showed a strong and constant increase in bottom temperature. The geographical distribution of the hydrological groups (Fig. 3) indicates geographical consistency in the groups, i.e. similar hydrological characteristics were spread over large cohesive regions rather than following a small patchy distribution. 

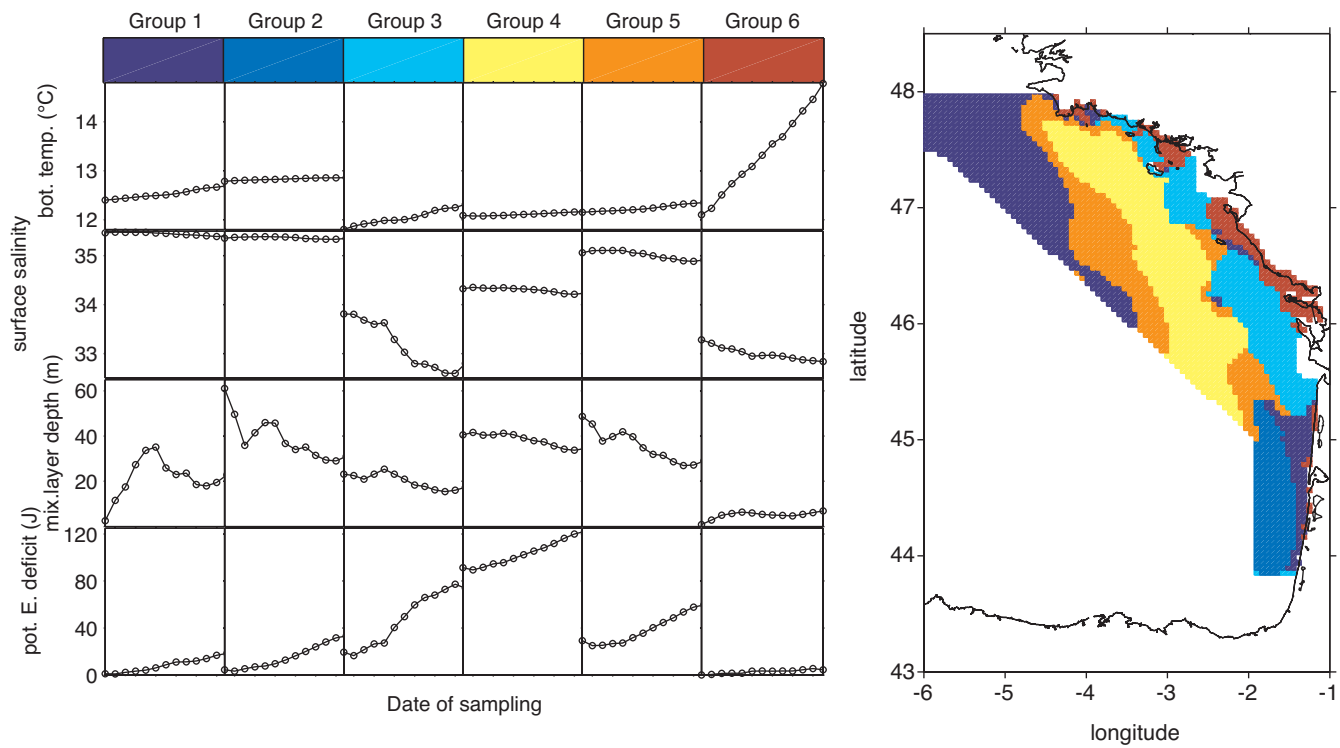

FIG. 3. - Typology of the Bay of Biscay hydrology based on dynamic clustering (see method section for details). Mean temporal changes in the four hydrological parameters for each group (left) and geographical distribution of the 6 hydrological groups (right).

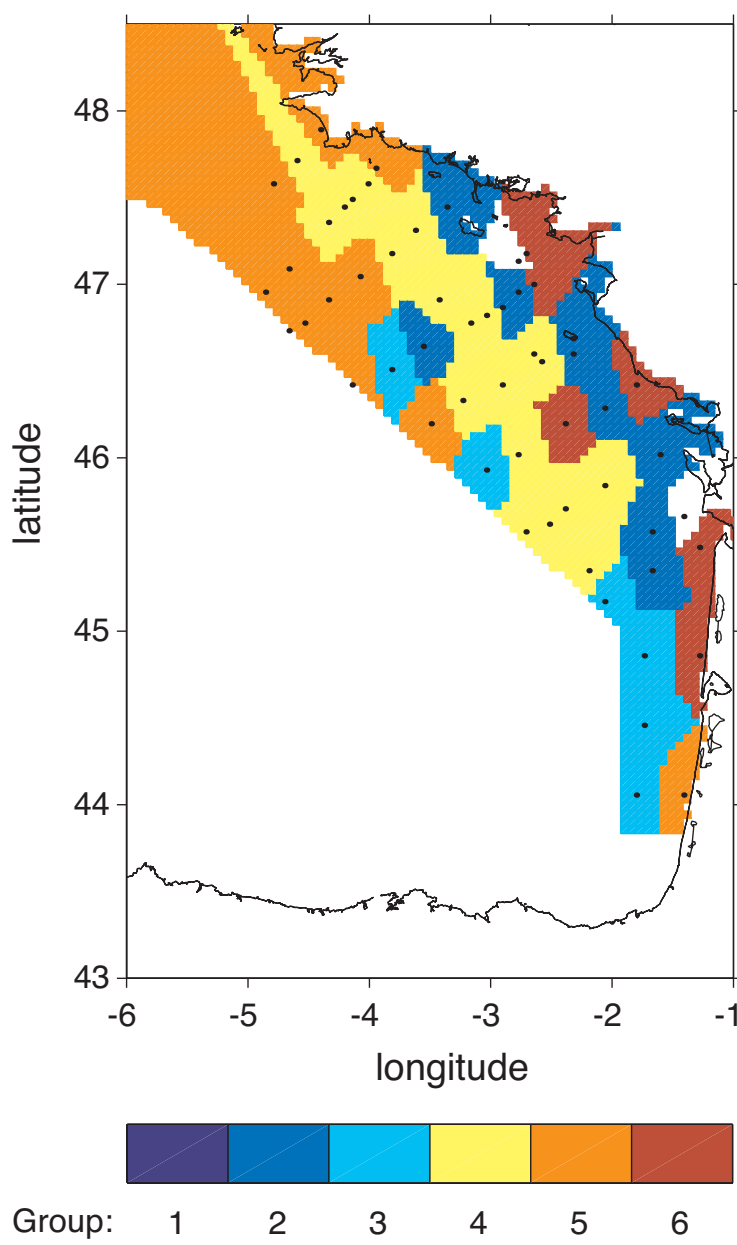

FIG. 4. - Typology of the Bay of Biscay hydrology in spring 2000 based on clustering of the stations sampled during the PEL2000 cruise. Sampling stations are indicated with black dots. Each colour corresponds to a distinct hydrological group, as defined in Figure 2 (note that group colour is independent from Figure 3).

\section{Clustering from the cruise stations only}

The above dynamic clustering can only be performed on simulated data for which hydrological conditions are known at each grid point for the whole duration of the cruise. In the field, data are only available at the specific stations (Fig. 1) and for a single date at each location. Therefore, the typology can only be constructed using a 'static' clustering approach and assuming that temporal changes in hydrography are negligible when compared to spatial variations. This typology is presented in Figure 4. The central region (group 4), which was clearly identified by dynamic clustering, was well captured when only the stations from the cruise sampling plan were used. The same is true for the southwestern area and for the coastal strip. On the other hand, areas surrounding the central region had a different spatial organisation from that obtained with dynamic clustering. This reflects the rapid changes in hydrography in these regions, which cannot be captured by unique hydrological sampling at each station.

\section{Comparison of model with observation}

For each hydrological station, the model and observations were compared on the basis of the four hydrological parameters retained: bottom temperature, surface salinity, potential E. deficit and mixed layer depth. It is clear from Figure 5 that not all parameters were simulated with the same accuracy by the hydrodynamic model. The mixed layer depth 


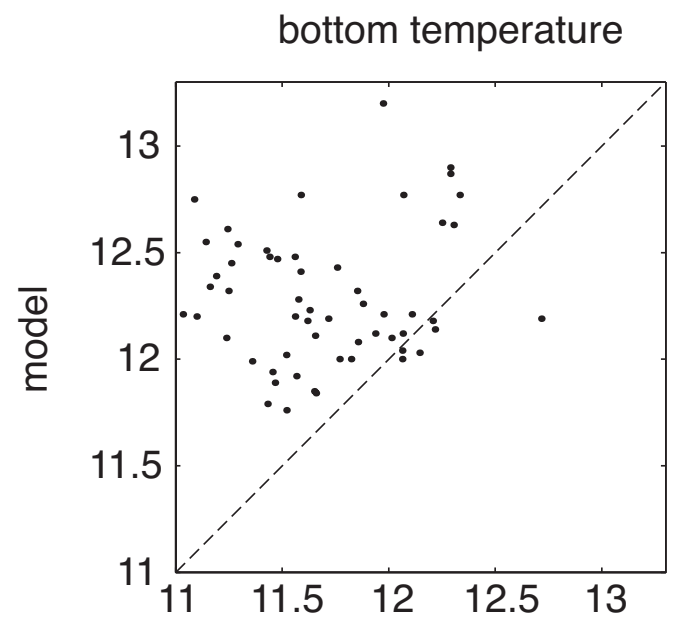

mixed layer depth

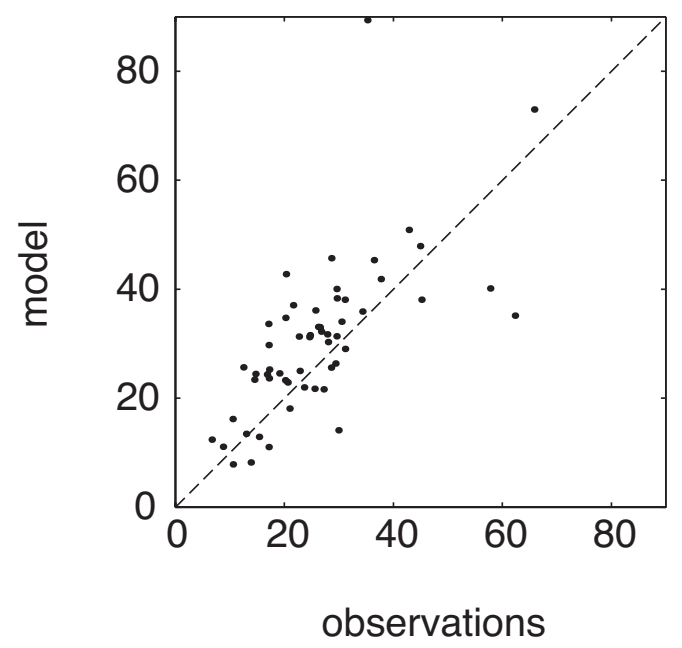

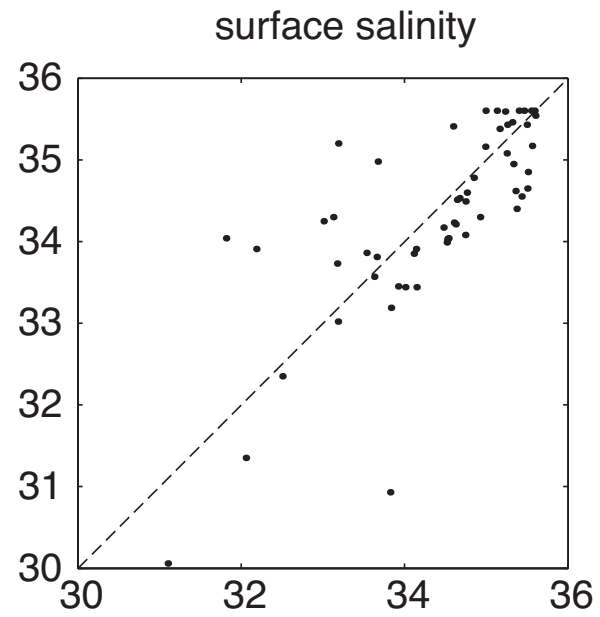

Pot E. deficit

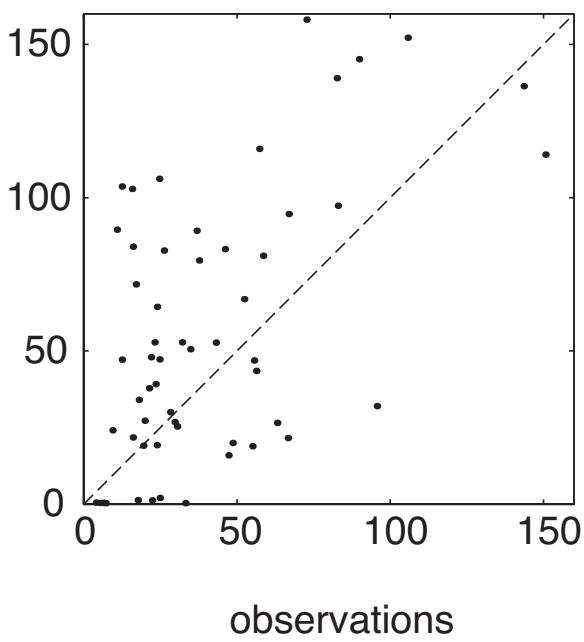

FIG. 5. - Comparison of observed (x-axis) and modelled (y-axis) hydrological parameters. Each value corresponds to a station sampled during the PEL2000 cruise. Corresponding model estimates are taken from the nearest grid point, and the nearest date.

appeared to be well captured by the model, but conversely, the potential energy deficit simulations were quite different from the observations, probably due to a slight inaccuracy in the surface salinity estimates. It appears that the model has difficulties in reproducing the cold bottom temperatures associated with a hydrological structure known as the "cold pool' (for details, see Vincent, 1973).

\section{DISCUSSION}

The definition of hydrological regions in the Bay of Biscay continental shelf has focused attention for a number of decades. Using results from hydrological cruises, several authors have reviewed the principal characteristics of the hydrological structures in the Bay of Biscay, their seasonal variability and to a lesser degree their interannual variations (Vincent, 1973; Le Cann, 1982; Koutsikopoulos and Le Cann, 1996; Puillat, et al., 2006). In previous works, the analysis of hydrological structures in the Bay of Biscay has been considered with a static view, i.e. the short term (intra-seasonal) variations in hydrological characteristics have been left aside. This has been so for two main reasons: first, ignoring short term variability does not preclude describing important hydrological entities, and second, there was no access to high frequency and large-scale hydrological data. This second reason is now partly overcome by the availability in 3D hydrodynamic model output for the Bay of Biscay.

In biological terms, the short-term fluctuations in hydrology are critical-in particular during the 
spring season-because they are often responsible for the onset, maintenance or decline in primary production, for the aggregation/concentration of planktonic predators and preys, and ultimately for the distribution of planktivorous fish species and survival of their larvae and juveniles (Vincent and Kurc, 1969; Arbault and Lacroix, 1977; Castel, 1993; Poulet, et al., 1996; Varela, 1996; Borja, et al., 1998; Bergeron, 2000; Allain, et al., 2001). Therefore, it is critical for biological studies that a typology of hydrodynamic structures incorporates the evolution of the water column properties over time. In this study we have presented an attempt to apply such a typology on a limited data set, the spring cruise undertaken in year 2000, and using the output from a 3D hydrodynamic model. Our results show that it is possible to define a limited number of regions in the Bay of Biscay where hydrological conditions and their associated temporal changes are distinct.

One important result from this analysis is the existence in the central area of the northern part of the shelf of a large region (group 4) that appears to be stable over time and strongly structured vertically (a deep mixed layer and a high potential energy deficit). This structure is well characterised by dynamic clustering but also when data from the cruise sampling plan are used. It is therefore reasonable to conclude that the current sampling strategy is adapted to the identification of this structure. The coastal region also forms an independent entity that is well defined in the two clustering methods. This was to be expected, since it is radically distinct from the rest of the continental shelf, with a very low surface salinity (spread from river plumes) and a shallow depth being responsible for a shallow mixed layer and a rapid increase in surface temperature. Conversely, the areas surrounding group 4 are highly dynamic and displayed rapid changes in at least one of the four hydrological parameters during the time of the cruise. Consequently, the corresponding groups revealed by dynamic clustering were not matched by static clustering, i.e. the sampling plan did not allow for a clear identification of hydrological regions, because the analysis was corrupted by the temporal changes taking place during the 26 days of the cruise. This can become problematic when one is interpreting the results from the cruise hydrological profile, as in this case one can hardly conclude on temporal versus spatial differences in hydrology. Because these areas are highly dynamic, the method used to separate the regions is likely to be less robust, i.e. more sensitive to hydrodynamical model specifications and clustering parameterisation. One major constraint is the ability of the numerical model to simulate faithfully the parameters used in the analysis. Our results suggest that the model performs well for estimating the mixed layer depth and surface salinity but has less capabilities for reproducing bottom temperatures and potential energy deficit. Systematic overestimation of bottom temperature seems to result from a long term drift in the initial condition of the model, which is most apparent towards the end of the simulation period, i.e. in 2000. Small discrepancies in surface salinity have a large impact on potential energy deficit calculation, so despite a good agreement between observed and modelled surface salinity, there are differences between the simulated and observed potential energy deficit. Differences between observations and simulations can also result from slight discrepancies in the spatial distribution of hydrological structures. Despite these limitations, the use of the hydrodynamic model associated with a dynamic clustering technique appears to provide an adapted tool to complement non-synoptic hydrological observations from field surveys. This tool will become more powerful as improvements in the physical model are made and current limitations are reduced.

Finally, it is noteworthy that the main hydrological entity identified in this analysis (central northern shelf region, group 4) corresponds to a region that is known to be a relative biological desert with regard to fish spawning in spring. Arbault and Lacroix (1977) already noted from data collected over a 10 -year period that the area appears infertile for sardine, even during the period of peak spawning. Similarly, the results from several years of fish egg sampling (Motos, et al., 1996) show that anchovy eggs are not sampled in this region, whereas they can be collected in the surrounding areas. In 2000 this area was also deprived of sardine and anchovy eggs.

Several years of model simulation and survey data are now available to (1) test whether the method developed here performs well in different climatic situations, (2) determine to what extent the large and stable hydrological region identified is a recurrent feature of the Bay of Biscay spring hydrography and (3) evaluate the influence of long-term climatic changes (Planque et al., 2003) on spring hydrodynamic features on the Bay of Biscay shelf. 


\section{ACKNOWLEDGEMENTS}

K-means clustering was performed using the SOM Toolbox 2.0 software library for Matlab, copyright (C) 1999 by Esa Alhoniemi, Johan Himberg, Jukka Parviainen and Juha Vesanto. The authors wish to thank the technical and scientific crew of the $\mathrm{R} / \mathrm{V}$ Thalassa during the cruise PEL2000. This work was carried as part of the European project PELASSES, the French National Programme PNEC (National Coastal Environment Programme), and the FOREVAR (Meso-scale environmental forcing and variability of pelagic populations in the Bay of Biscay) project of Ifremer.

\section{REFERENCES}

Allain, G., P. Petitgas and P. Lazure. - 2001. The influence of mesoscale ocean processes on anchovy (Engraulis encrasicolus) recruitment in the Bay of Biscay estimated with a three-dimensional hydrodynamic model. Fish. Oceanogr., 10: 151-163.

Arbault, S. and N. Lacroix. - 1977. Oeufs et larves de clupeides et engraulides dans le golfe de Gascogne (1969-1973). Distribution des frayères. Relations entre les facteurs du milieu et la reproduction. Rev. Trav. Inst. Pêches Marit., 41: 227-254.

Bardey, P., P. Garnesson, G. Moussu and L. Wald. - 1999. Joint analysis of temperature and ocean colour satellite images for mesoscale activities in the Gulf of Biscay. Int. J. Remore Sensing, 20: 1329-1341.

Bergeron, J.P. - 2000. Effect of strong winds on the nutritional condition of anchovy (Engraulis encrasicolus L.) larvae in the Bay of Biscay, Northeast Atlantic, as inferred from an early field application of the DNA/C index. ICES J. Mar. Sci., 57: 249-255.

Borja, A., A. Uriarte, J. Egaña, L. Motos and V. Valencia. - 1998. Relationships between anchovy (Engraulis encrasicolus) recruitment and environment in the Bay of Biscay (1967-1996). Fish. Oceanogr., 7: 375-380.

Borja, A., A. Uriarte, V. Valencia, L. Motos and A. Uriarte. - 1996. Relationships between anchovy (Engraulis encrasicolus L.) recruitment and the environment in the Bay of Biscay. Sci. Mar., 60(Suppl. 2): 179-192.

Castel, J. - 1993. Long-term distribution of zooplankton in the Gironde estuary and its relation with river flow and suspended matter. Cah. Biol. Mar., 34:

Davies, D.L. and D.W. Bouldin. - 1979. A cluster separation measure. IEEE T. Pattern. Anal., 1: 224-227.

Jain, A.K. and R.C. Dubes. - 1988. Algorithms for clustering data. Prentice Hall. Englewoods Cliffs, N.J.

Koutsikopoulos, C. and B. Le Cann. - 1996. Physical processes and hydrological structures related to the Bay of Biscay anchovy. Sci. Mar., 60(Suppl. 2): 9-19.

Labry, C., A. Herbland, D. Delmas, P. Laborde, P. Lazure, J.M. Froidefond, A.-M. Jégou and B. Sautour. - 2001. Initiation of winter phytoplankton blooms within the Gironde plume waters in the Bay of Biscay. Mar. Ecol. Prog. Ser., 212: 117-130.

Lazure, P. and A.-M. Jégou. - 1998. 3D modelling of seasonal evolution of Loire and Gironde plumes on Biscay bay continental shelf. Oceanol. Acta, 21: 165-177.

Le Cann, B. - 1982. Evolution annuelle de la structure hydrologique du plateau continental au sud de la Bretagne: modélisation numérique. Thèse de 3ème cycle. Université de Bretagne Occidentale.

Motos, L., A. Uriarte and V. Valencia. - 1996. The spawning environment of the Bay of Biscay anchovy (Engraulis encrasicolus L.). Sci. Mar., 60: 117-140.

Planque, B., P. Beillois, A.-M. Jégou, P. Lazure, P. Petitgas and I. Puillat. -2003 . Large scale hydroclimatic variability in the Bay of Biscay. The 1990s in the context of interdecadal changes. ICES mar. Sci. Symp., 219: 61-70.

Poulet, S.A., M. Laabir and Y. Chaudron. - 1996. Characterisitc features of zooplankton in the Bay of Biscay. Sci. Mar., 60(Suppl. 2): 79-95.

Puillat, I., P. Lazure, A.-M. Jégou, L. Lampert and P. Miller. 2006. Mesoscale hydrological variability induced by northwesterly wind on the French continental shelf of the Bay of Biscay. Sci. Mar., 70(Suppl. 1):

Varela, M. - 1996. Phytoplankton ecology in the Bay of Biscay. Sci. Mar., 60(Suppl. 2): 45-53.

Vincent, A. - 1973. Les variations de la situation thermique dans le golfe de Gascogne en 1969 et 1979. Rev. Trav. Inst. Pêches Marit., 37: 5-18.

Vincent, A. and G. Kurc. - 1969. Les variations de la situation thermique dans le golfe de Gascogne et leur incidence sur l'écologie et la pêche de la sardine en 1968. Rev. Trav. Inst. Pêches Marit., 33: 203-212.

Received June 28, 2002. Accepted November 24, 2004.

\section{APPENDIX}

\section{Calculation of mixed-layer depth and potential energy deficit}

The mixed layer depth is calculated according to a 2-layer model. In this model, the water column is constituted of 2 homogeneous layers separated by a sharp pycnocline. The average density in the 2-layer model is that observed in the water column, the upper layer density is the observed surface density and the lower layer density is the observed bottom density. The mixed layer depth $Z_{m}$ is then derived using the following equation:

$$
Z_{m}=Z_{1} \frac{\rho_{m}-\rho_{1}}{\rho_{0}-\rho_{1}}
$$

where $\rho_{0}$ is the surface density, $\rho_{1}$ the bottom density, $\rho_{m}$ the mean density and $Z_{1}$ the water column total height.

The potential energy deficit is the amount of energy required to vertically mix the water column, so that the density is even from top to bottom. Potential energy deficit is given by the equation:

$$
\Phi=\frac{1}{H+\xi} \int_{-H}^{\xi}\left(\bar{\rho}-\rho_{z}\right) g z d z
$$

where $\bar{\rho}=\frac{1}{H+\xi} \int_{-H}^{\xi} \rho_{z} d z$

$\rho_{\mathrm{Z}}$ : density at depth z, $H$ : water column height, $\xi$ : sea surface free height 